Pamiętnik Literacki 2021, 3, s. 279

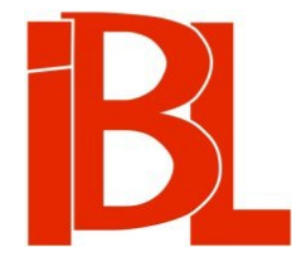

\title{
Dwa nowo odnalezione treteriana
}

Alicja Bielak 


\title{
3. D Y S K U J E - K O R E S P N D E N C J A
}

Pamiętnik Literacki CXII, 2021, z. 3, PL ISSN 0031-0514

DOI: $10.18318 / \mathrm{pl} .2021 .3 .16$

\author{
ALICJA BIELAK Instytut Filozofii i Socjologii PAN, Warszawa \\ ORCID: 0000-0003-0701-0634
}

\section{DWA NOWO ODNALEZIONE TRETERIANA}

Spuścizna rękopiśmienna Tomasza Tretera (1547-1610), pisarza, rytownika, sekretarza na dworze kardynała Stanisława Hozjusza, nadal nie jest całościowo opracowana. Dotychczas znana już badaczom korespondencja kanonika warmińskiego wciąż pozostaje w rękopisach, czekając na podobne opracowanie edytorsko-wydawnicze jak w wypadku zbioru listów Stanisława Reszki, towarzysza Tretera na dworze Hozjusza. Udało mi się zidentyfikować kolejny autograf Tretera, a mianowicie brudnopis ze szkicami emblematów przechowywany obecnie w Biblioteca Civica Angelo Mai w Bergamo (rkps MM 378). Wedle datacji odnotowanej przez Tretera wewnątrz kodeksu wpisy powstawały między 20 VI 1569 a 2 III 1575. Autograf zawiera nieznane dotąd emblematy Tretera oraz pierwopis dzieła Symbolica vitae Christi meditatio (wyd. Brunsbergae, Georg[ii] Schönfels, 1612). Omówienie manuskryptu, a także transkrypcja i tłumaczenie 25 emblematów Tretera (w przekładzie Anny Treter) nieuwzględnionych w braniewskiej edycji ukaże się niebawem na łamach „Terminusa” (t. $23\langle 2021\rangle$, z. $3\langle 60\rangle)$.

Kolejnym treterianum, które udało się zidentyfikować, są iluminacje w anonimowym Graduale de sanctis (z drugiej połowy XVII w.), przechowywanym w Bibliotece Karmelitów na Piasku w Krakowie (BKKr, rkps perg. 5). Kodeks stanowi ewenement na skalę europejską ze względu na występowanie 31 inicjałów o strukturze emblematycznej towarzyszących zapisom nutowym, z którymi elementy słowno-obrazowe wchodzą w interakcję, tworząc multimedialne konstrukcje. Aż 22 z 31 emblematycznych inicjałów wzorowane są na emblematach z druku Symbolica vitae Christi meditatio. W ozdobne inicjały zostały wmalowane ikony emblematów, a także wpisane, towarzyszące im w druku, inskrypcje. Obecnie przygotowuję wraz $\mathrm{z}$ dr. Markiem Bebakiem (Uniwersytet Jagielloński) monograficzne opracowanie zabytku, które ukaże go zarówno na tle tradycji emblematów muzycznych, jak i w kontekście potrydenckiego repertuaru chorałowego.

Kwerendy, które umożliwiły identyfikację wspomnianych rękopisów, odbyłam w ramach projektu Emblematy medytacyjne w Rzeczpospolitej od XVI do XVIII wieku: źródła, realizacje i cele, finansowanego przez NCN (Preludium, 2018/31/N/ HS2/01187). 